\title{
34 years of investigation in the Rhine River at Ludwigshafen, Germany - trends in Rhine fish populations
}

\author{
Sascha Pawlowski ${ }^{*}$, Juergen Jatzek ${ }^{2}$, Thomas Brauer ${ }^{2}$, Katja Hempel ${ }^{3}$ and Roland Maisch ${ }^{2}$
}

\begin{abstract}
Background: The Rhine-Neckar region is one of the most urbanised areas along the Rhine River and the world's largest industrial site, BASF SE, is located here at Ludwigshafen am Rhein. When the water quality dropped to its lowest values in the 1970s, BASF SE implemented a sewage treatment plant at its production site. In addition, electrofishing at this site has been carried out at regular intervals since 1976 in order to monitor changes in the fish population, whereby clear trends in both fish diversity as well as abundance have been noted.

Results: Especially rheophilic fish species such as asp Aspius aspius (L.), barbel Barbus barbus (L.) and nase Chondrostoma nasus (L.) which were rarely found during the first catching period (1976 - 1980) were then caught in increasing numbers and abundance. Starting with 6 to 8 fish species per catch in the 1970s, the number has raised to 25 fish species (including 4 neozoans) in recent catches. Overall 31 species have been monitored in the last 34 years.

Conclusions: This indicates good river water quality and an increase in fish biodiversity along the BASF site at Ludwigshafen over the last three decades. However, focussing on the past decade, new invasive fish species such as the sunfish Lepomis gibbosus (L.) and three gobies have been found in high densities along the river banks which might have an impact on the fish population in this area in the future.
\end{abstract}

Keywords: Rhine fish population, Electrofishing, Water quality, Fish species dynamics

\section{Background}

The Rhine is one of the most "mainstreamed" rivers in Europe, balancing several aspects including transport, drinking water supply, cooling water, energy reservoir, as well as being used for effluent disposal, and providing leisure activities such as fishing (Figure 1). The former structure of the river itself had been dramatically changed as a result of the invasive canalisation project by Tulla at the beginning of the 19th century, affecting the entire river from Rheinfelden (Switzerland) to Rotterdam (The Netherlands) [1]. Based on historical fishing data, it can be concluded that this structural change also influenced the fish fauna of the Rhine [2-9]. However, especially after the Second World War, a drop in both fish species number and abundance was observed due to the

\footnotetext{
* Correspondence: sascha.pawlowski@basf.com

'Department of Product Safety, BASF SE, GUP/PA, Z 570, Ludwigshafen 67056, Germany

Full list of author information is available at the end of the article
}

contamination of the river as a consequence of increasing industrialisation and further urbanisation of the Rhine valley [10-12]. In the 1970s water quality dropped to its lowest levels resulting in the implementation of various Rhine restoration programs, including the reintroduction of endangered and/or temporarily extinct fish species [13-16]. One of the commitments was the installation of the world's largest industrial sewage treatment plant (approx. 110 million $\mathrm{m}^{3}$ waste water per year, equivalent to a city of approx. 3 million inhabitants) located at the BASF SE site in Ludwigshafen am Rhein (Rhine-Neckar Metropolis Region, Germany) [12,17]. Along with this project, electrofishing was carried out by BASF SE at regular intervals in order to investigate potential trends in fish populations close to the industrial site in Ludwigshafen [18]. Starting in 1976, the species caught have been identified, their relative abundance determined and their overall health status observed. 

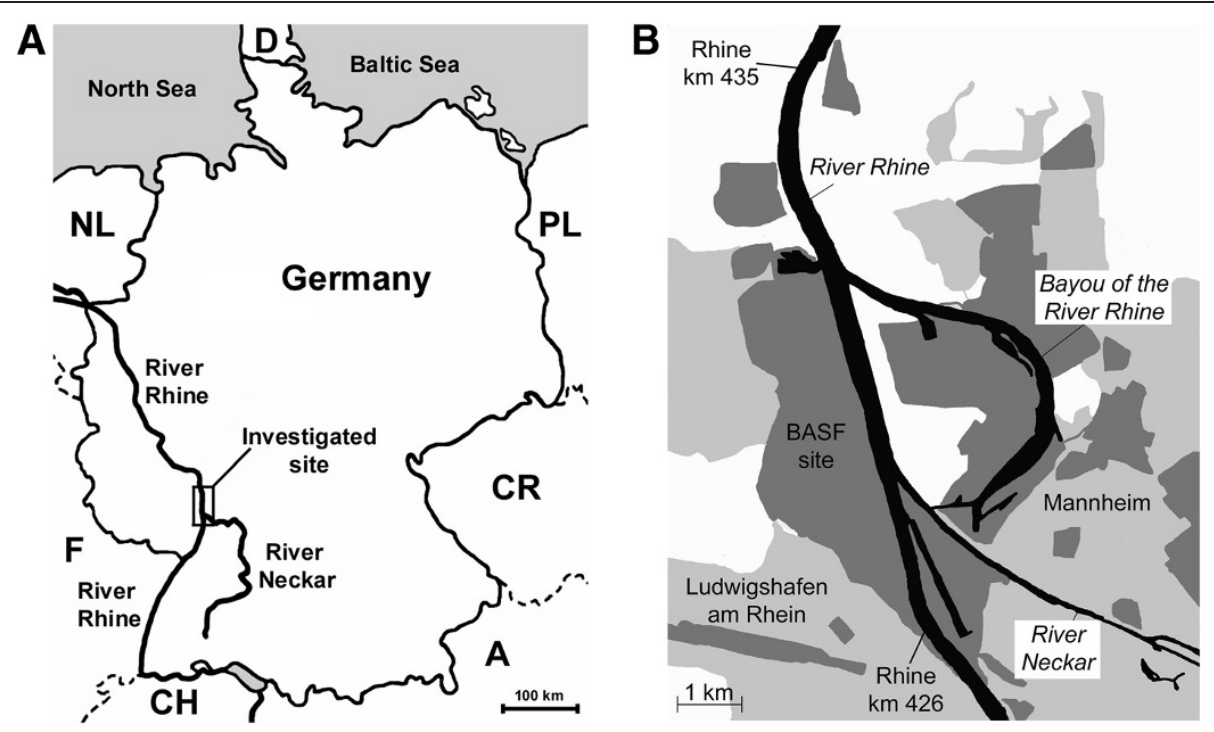

Figure 1 Schematic map of Germany (a) and the Rhine-Neckar region (b) including the Rhine River site investigated (km 426 - 435 ). Black - aquatic areas; dark grey - industrialised area; light grey - urbanised area; white - agricultural, nonurban and forest area.

\section{Results}

\section{Number of fish species caught per sampling}

Starting in December 1976, 6 fish species were found along the Rhine site at BASF SE Ludwigshafen (Figure 2). From 1981 until 1990 the number of fish species found varied from 8 in 1983 to 11 fish per sampling in 1985. In the next decade, a minimum of 10 fish species per sampling (1992) and a maximum of 15 fish species per sampling (1995) were found. From 2001 until 2010 the number of fish species found further increased and ranged from 12 (in 2002) to 17 (in 2006). There is still a high variation in fish species caught during the different samplings. Overall there was a statistically significant $(p \leq 0.05)$ increase in the species number over the observation period as proven by linear regression by time (SAS procedure Proc Reg).

\section{Number of fish species found per time period}

During the four time periods, the total number of fish species found increased (Figure 3). During the first decade 15 fish species were located at the BASF SE site (Table 1). During the second period up to 22 species

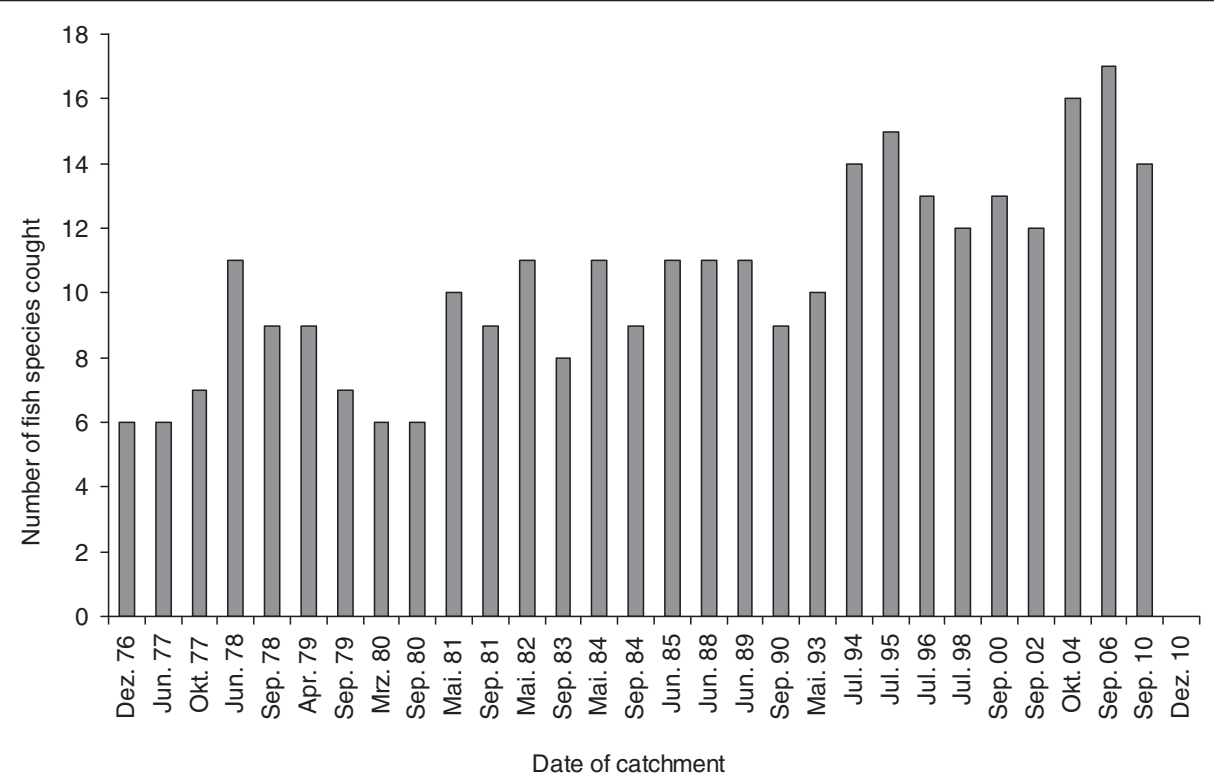

Figure 2 Number of fish species caught on each electrofishing occasion along the BASF SE site at Ludwigshafen am Rhein. 


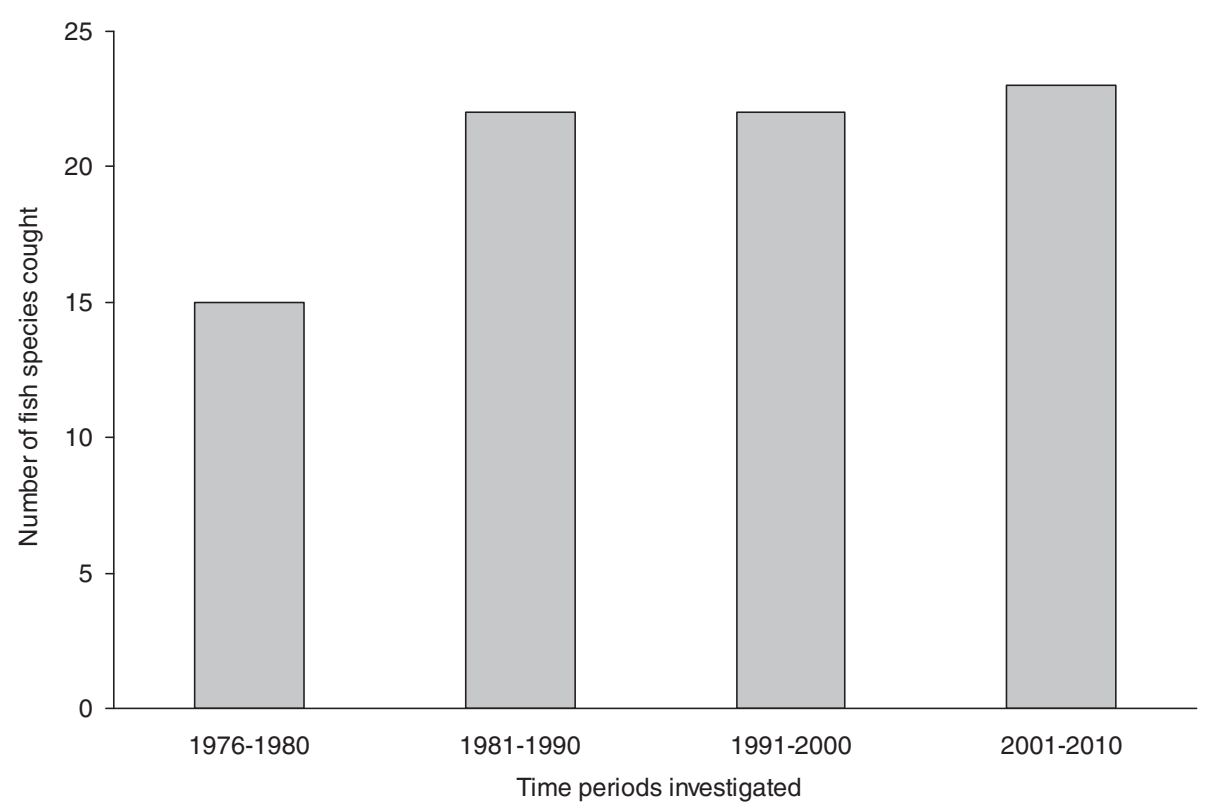

Figure 3 Total number of fish species caught during the four sampling periods from 1976 until 2010 along the BASF SE site at Ludwigshafen am Rhein.

were found. In the third period the maximum number of fish species remained the same (22). However, three further fish species were first observed in this river section and three other ones were then absent. In the most recent decade, 24 fish species including three gobidae and one cyclostoma (namely Lampetra planeri (Bloch 1784)) were found. Again, some species, such as $S$. trutta forma fario, S. trutta trutta, L. lota and C. taenia, were absent in this electrofishing period.

\section{Relative abundance and trends in the fish community}

During the 34-year investigation, 5 out of 31 fish species were found at each sampling period (100\% abundance), i.e. C. carpio, P. fluviatilis, R. rutilus, S. erythrophthalmus and $A$. anguilla (Table 2). Fish species such as A. aspius, B. barbus, C. nasus, S. glanis and G. cernua were absent within the first observation period, but their relative abundance constantly increased to 75 (C. nasus) and $100 \%$ (all other four species), up to 2010. For S. trutta fario, S. trutta trutta and E. lucius a decrease in species abundance could be observed during the entire catching period. All other species were either commonly found (such as A. anguilla or R. rutilus) or only found occasionally (such as L. lota or C. taenia) and thus, no specific trends in relative abundance could be determined.

During the first catching period, nine endangered fish species listed in the red list of Germany and the Rhineland Palatinate were found at this site, whereas in the last decade of catches 14 fish species were found (Table 1). Only S. trutta fario, S. trutta trutta and C. taenia were absent.
Statistical evaluation as shown in Table 2 revealed a statistically significant increase for the following species: B. barbus, S. cephalus, L. leuciscus, G. cernua, C. nasus, A. aspius, L. gibbosus, and S. glanis. A statistically significant decrease was only seen for E. lucius. For all other species no statistically significant changes were observed.

\section{Overall health status}

Visual assessment of the overall health status, any external abnormalities, and infection status with ectoparasites showed no remarkable results [19]. Only sporadic nematodes infections of the airbladder of the eel in 1988 and 1989 are worth noting.

\section{Discussion}

The investigation of the fish population along the Rhine from kilometre 426 to 435 (including the BASF SE industrial site) over the past 34 years shows an overall increase in both species number and abundance. In fact, the fish biodiversity has increased during the whole observation period. Especially rheopilic species, such as A. aspius, B. barbus, S. cephalus and C. nasus, which were either absent or only rarely observed in the first sampling period, are now found regularly in the Rhine along this site. Although water flow has not changed essentially during this time, water quality has improved dramatically in recent years, thus improving the habitat of endangered fish species. In fact, both the nutrition load (such as nitrates and phosphates) and the concentration of organic contaminants decreased due to installation of sewage treatment plants (both municipal and 
Table 1 Species list and relative abundance of fish found during each of the four sampling periods at the BASF site at Ludwigshafen am Rhein

\begin{tabular}{|c|c|c|c|c|c|c|c|}
\hline \multicolumn{2}{|c|}{ Fish species and cyclostomes } & \multirow{2}{*}{$\begin{array}{l}\text { Conservation } \\
\text { status Germany }\end{array}$} & \multirow{2}{*}{$\begin{array}{l}\text { Conservation status } \\
\text { Rhineland-Palatinate }\end{array}$} & \multicolumn{4}{|c|}{ Frequency of occurrence [\%] } \\
\hline Common name & Scientific name & & & $\begin{array}{c}1976-1980 \\
(n=9)\end{array}$ & $\begin{array}{c}1981-1990 \\
(n=10)\end{array}$ & $\begin{array}{c}1991-2000 \\
(n=6)\end{array}$ & $\begin{array}{c}2001-2010 \\
(n=4)\end{array}$ \\
\hline$\overline{\text { Asp }^{1}}$ & Aspius aspius & - & 2 & 0 & 20 & 100 & 100 \\
\hline Barbel $^{1}$ & Barbus barbus & 2 & 2 & 0 & 10 & 83 & 100 \\
\hline Bighead goby ${ }^{2}$ & Neogobius kessleri & - & - & 0 & 0 & 0 & 25 \\
\hline Bleak & Alburnus alburnus & - & - & 78 & 100 & 67 & 75 \\
\hline Bream & Abramis brama & - & - & 100 & 100 & 100 & 50 \\
\hline Brown trout & Salmo trutta fario & - & 2 & 33 & 10 & 17 & 0 \\
\hline Burbot & Lota lota & 2 & 2 & 0 & 20 & 34 & 0 \\
\hline Carp $^{1}$ & Cyprinus carpio & 2 & - & 11 & 20 & 34 & 75 \\
\hline Catfish $^{1}$ & Silurus glanis & 2 & 3 & 0 & 40 & 100 & 100 \\
\hline$\overline{\text { Chub }^{1}}$ & Squalius cephalus & - & - & 33 & 90 & 100 & 100 \\
\hline Dace & Lenciscus lenciscus & 3 & - & 0 & 10 & 0 & 75 \\
\hline Eurasian ruffe $^{1}$ & Gymnocephalus cernua & - & - & 0 & 40 & 83 & 100 \\
\hline European brook lamprey & Lampetra planeri & 2 & 2 & 0 & 0 & 0 & 50 \\
\hline European bullhead & Cottus gobio & 2 & 2 & 0 & 0 & 0 & 25 \\
\hline European eel & Anguilla anguilla & 3 & 4 & 100 & 100 & 100 & 100 \\
\hline European perch & Perca fluviatilis & - & - & 100 & 100 & 100 & 100 \\
\hline Gudgeon & Gobio gobio & - & 3 & 11 & 60 & 50 & 50 \\
\hline Nase $^{1}$ & Chondrostoma nasus & 2 & 2 & 11 & 10 & 34 & 75 \\
\hline $\mathrm{Pike}^{3,4}$ & Esox lucius & 3 & 2 & 78 & 60 & 34 & 25 \\
\hline Pikeperch $^{2}$ & Sander lucioperca & - & 4 & 56 & 60 & 67 & 75 \\
\hline Prussian carp, gibel carp & Carassius gibelio & - & - & 0 & 20 & 0 & 0 \\
\hline Roach & Rutilus rutilus & - & - & 100 & 100 & 100 & 100 \\
\hline Round gobi ${ }^{2}$ & Neogobius melanostomus & - & - & 0 & 0 & 0 & 25 \\
\hline Rudd & Scardinius erythrophthalmus & - & 4 & 100 & 100 & 100 & 100 \\
\hline Sea trout & Salmo trutta trutta & 2 & 1 & 33 & 10 & 17 & 0 \\
\hline Silver bream & Blicca bjoerkna & - & - & 0 & 0 & 0 & 25 \\
\hline Spined loach & Cobitis taenia & 2 & 2 & 0 & 0 & 17 & 0 \\
\hline Spirlin & Alburnoides bipunctatus & 2 & 2 & 0 & 0 & 0 & 25 \\
\hline Sunfish $^{2,3}$ & Lepomis gibbosus & - & - & 0 & 0 & 50 & 25 \\
\hline Tench & Tinca tinca & - & - & 33 & 30 & 0 & 0 \\
\hline Tubenose goby ${ }^{2}$ & Proterorhinus marmoratus & - & - & 0 & 0 & 0 & 25 \\
\hline
\end{tabular}

${ }^{1}$ Numbers increased during the observation period.

${ }^{2}$ Neozoa.

${ }^{3}$ Found mainly at the lentic harbour side.

${ }^{4}$ Numbers decreased during the observation period.

industrial) along the Rhine [20,21]. Furthermore, the implementation of the large industrial sewage treatment plant at BASF SE Ludwigshafen may have had a major impact on water quality.

The reduction in organic carbon load also had a positive effect on the oxygen content of the water, thus increasing the survival rate of the more oxygen-dependent fish species historically typical of this section of the Rhine (socalled barbel region). In the early 1970s, oxygen concentrations were close to the lower limit for fish survival, resulting in a reduction of the macroinvertebrate species to about one third of the original 80 species known to be native in this area [22]. So more robust fish species like $R$. rutilus/S. erythrophthalmus (these species were not exactly differentiated at that time), A. brama and $A$. anguilla were the predominant species in this section of the Rhine. This is in line with previous observations from the late 1960s when $R$. rutilus and A. brama were found to be most abundant and fish species such as B. barbus, S. cephalus and S. lucioperca were rare in this area [23]. However, by the early 1990s, water quality measurements showed oxygen concentrations close to $100 \%$ 
Table 2 Statistically significance of increases or decreases in numbers over the entire observation period

\begin{tabular}{lcc}
\hline Fish species & $\begin{array}{c}\text { Statistically } \\
\text { increased over } \\
\text { observation } \text { period }\end{array}$ & $\begin{array}{c}\text { Statistically } \\
\text { decreased over } \\
\text { observation } \text { period }\end{array}$ \\
\hline Aspius aspius & yes & no \\
\hline Barbus barbus & yes & no \\
\hline Chondrostoma nasus & yes & no \\
\hline Esox lucius & no & yes \\
\hline Gymnocephalus cernua & yes & no \\
\hline Lepomis gibbosus & yes & no \\
\hline Leuciscus cephalus & yes & no \\
\hline Leuciscus leuciscus & yes & no \\
\hline Silurus glanis & yes & no \\
\hline
\end{tabular}

Wald Chi Square test (logistic regression) with Significance level of 5\%.

saturation with corresponding $\mathrm{NH}_{4}-\mathrm{N}, \mathrm{NH}_{3}-\mathrm{N}$ and P-total concentrations of $<0.5,<4$ and $\leq 20 \mathrm{mg} / \mathrm{L}$, respectively [21]. The improvement in water quality around the BASF SE site is in line with the overall improved water quality observed at other sites along the Rhine [14,24].

Rheophilic fish have increased in the past two decades but were low in numbers for the first 15 years [18]. In fact, taking in to account the whole time period of investigation this increase in the number of species found was highest between the first two decades (1976 1980 versus 1981 - 1990). Based on the historic data 48 fish species were found to be indigenous for the river Rhine, however recatchment analysis revealed that only 42 fish species were found in 1986/1987 [25]. Additionally, this number of fish species refers to the whole river section including also estuaries and bayous and is therefore not restricted to the main river section investigated [26]. This would explain why fish species such as the Coregonus spp. L. (2 species), Osmerus eperlanus L., Misgurnus fossilis L., Rhodeus amarus (Bloch), Gasterosteus aculeatus L. and Pungitius pungitius L. were listed as indigenous for the river but should not be considered to inhabit this specific area [27].

Those fish species found are representative of the Rhine, and can be found further upstream at the socalled Hochrhein (from Lake Constance to Basel, Switzerland), thus confirming the good water quality and high oxygen content [28]. Nevertheless it cannot be excluded that rheophilic fish species has recovered due to other reasons (e.g. fish passes). The wide variety of fish species caught at each sampling, however, can be explained by the method used as it is limited to the surface and river bank areas and thus strongly dependent on the given water flow conditions, which beyond water temperatures (high or low water; see Table 3) $[23,29,30]$. Despite these limitations, a clear trend in fish population dynamic can be seen during the past decades of investigation.
Table 3 Corresponding water levels and water temperatures on the month of electrofishing

\begin{tabular}{|c|c|c|}
\hline $\begin{array}{l}\text { Date of } \\
\text { fishing }\end{array}$ & $\begin{array}{l}\text { Water gauge }[\mathrm{m}] \\
\text { Mannheim }\end{array}$ & $\begin{array}{c}\text { Water temperature }\left[{ }^{\circ} \mathrm{C}\right] \\
\text { Ludwigshafen }\end{array}$ \\
\hline Dec 1976 & n. d. & 5.5 \\
\hline Jun 1977 & 3.82 & 17.1 \\
\hline Oct 1977 & 2.17 & 14.1 \\
\hline Jun 1978 & 4.35 & 16.8 \\
\hline Sep 1978 & 2.91 & 17.5 \\
\hline Apr 1979 & 3.50 & 9.7 \\
\hline Sep 1979 & n. d. & 18.5 \\
\hline Mar 1980 & n. d. & 7.9 \\
\hline Sep 1980 & n. d. & 17.8 \\
\hline May 1981 & n. d. & 13.9 \\
\hline Sep 1981 & n. d. & 18.2 \\
\hline May 1982 & 3.98 & 14.0 \\
\hline Sep 1983 & 2.92 & 18.5 \\
\hline May 1984 & 2.19 & 12.9 \\
\hline Sep 1984 & 3.10 & 17.5 \\
\hline Jun 1985 & 4.20 & 21.5 \\
\hline Jun 1988 & 4.12 & 17.9 \\
\hline Jun 1989 & 2.13 & 19.9 \\
\hline Sep 1990 & 1.67 & 19.0 \\
\hline May 1993 & 2.91 & 17.7 \\
\hline Jul 1994 & 2.90 & 23.9 \\
\hline Jul 1995 & 3.98 & 22.5 \\
\hline Jul 1997 & 2.39 & 19.7 \\
\hline Jul 1998 & 2.63 & 21.7 \\
\hline Sep 2000 & 2.80 & 19.0 \\
\hline Sep 2002 & n. d. & 18.6 \\
\hline Oct 2004 & n. d. & 15.8 \\
\hline Sep 2006 & n. d. & 20.1 \\
\hline Sep 2010 & 3.41 & 18.3 \\
\hline
\end{tabular}

n. d. - no data available.

In addition to the increase in species numbers, several other observations on fish fauna have been made which are not necessarily linked to the water quality improvements in this area in particular. Restocking measures which were carried out during the past tenth of years for S. salar, S. trutta and A. anguilla might also have and direct (species affected) or an indirect impact (predator) on the river rhine fish populations $[15,31,32]$. Nevertheless, the number of both S. trutta fario and S. trutta trutta has decreased over the past 34 years and are absent nowadays. These two species, however, have always been rare as they are more likely to be found in the lotic tributaries of the river (socalled trout region) than in the Rhine itself.

Furthermore, the S. glanis, G. cernua and C. carpio are not typical of the barbel region as they are more native 
to lentic habitats such as lakes and the lowlands of the Rhine. The increase in their relative abundance might be explained either by the direct connection to lentic harbours and bayous or especially by the rocky structure of the river bank which provides an excellent hiding habitat for at least the S. glanis and G. cernua. In addition, since the number of catfish was low in the Rhine in the past, this species was restocked several years ago and is now to be found in great numbers. Considering other species found more or less frequently over the 34-odd years of investigation, it should be mentioned that fish usually migrate along the river but show a preference for a specific river section (as indicated by trout or barbel or bream region). Thus, it is probable that a fish species can be found in a river section where they are not usually abundant. The E. lucius, for example, was usually caught in the lentic harbour at the BASF SE site which in fact is the more appropriate habitat than the river itself und thus their relative low abundance compared to P. fluviatilis and S. lucioperca is not unexpected [27].

Although the number of fish species has risen over the past 34 years, the species list differs from the one drawn up 100 years ago, since some anadromous fish such as the allis shad Alosa alosa (L.) and common sturgeon Acipenser sturio L. have been extinct for more than 60 years due to former river contamination (at the beginning of industrialisation), barricades along the length of the river and intensive fishing [33]. For the Atlantic salmon Salmo salar L. several reimplementation programmes were established in the late 1990s to restock populations [34]. This species has still to be found during the electrofishing procedure as the method used is limited to catches along the river banks rather than the middle of the river, and the number of returning $S$. salar is still low [30].

However, some new invaders have been observed: the North American sunfish L. gibbosus has been found in the area since the early 1990s, originating from either sport fisheries ( $1^{\text {st }}$ invasive period) or pet shop trading $\left(2^{\text {nd }}\right.$ invasive period). In 2010, high population densities of another invasive group of fish, the pontocaspian gobies (Fam. Gobidae), were noted. Although the exact species has not been determined, it is very likely that they found their way into the Rhine via the RhineMain-Danube Canal since at least the Proterorhinus marmoratus (Pallas 1814) was found in the River Main in the late 1990s [35]. Like the invasion of Danubian/ Caspian fish species also the Rhine macroinvertebrate fauna is highly affected by Danubian species [36].

Both sunfish and gobies are strong predators especially of young fish, but at least for the latter species there is little information on their possible impact on the Rhine fish community to date.
For some fish species found in the past one or two catching periods, such as the A. bipunctatus, L. leuciscus and the cyclostoma $L$. planeri, no definitive population trend analysis is currently available since the time period of their abundance is too short. However, as they are "native" to the barbel region it is very likely that their numbers will rise in future.

Overall, even in the highly industrialised river section at Ludwigshafen am Rhein, the Rhine fish population along with the water quality do not markedly differ from other comparable river sections, showing a good recovery over the past 34 years of investigations.

\section{Conclusions}

Overall, the water quality of the Rhine has improved since the 1970s as indicated by the number and species of fish collected by electrofishing in the period of investigation. The improvement of water quality is also enhancing the biodiversity of fishes in this river. Since the water quality has almost reached the optimum which can be expected for this river section (water quality index of about 2.0 - 2.3) the number of fish species found may likewise have reached maximum levels for this water quality. However, current trends indicate a shift towards invasive Neozoa so there might be a further biological impact on the Rhine fish population in future. Therefore, regular electrofishing is considered to be a valuable tool not only to monitor water quality but also to constantly investigate the fish populations along the BASF SE site with respect to new invaders and potentially new species.

\section{Methods}

Samples were taken by electrofishing at regular intervals between 1976 and 2010 along the left bank of the Rhine from Gate 6 of BASF SE (Rhine km 426) to Rheindürkheim (Rhine km 435, Figure 1).

Fish were caught using a small boat with equipment on board [18]. Briefly, a 500 volt (12 ampere) direct current generator was connected to an anode dip net (diameter of about $40 \mathrm{~cm}$; mesh width about $1 \mathrm{~cm}$ ) as used to catch the fish. Fishing takes places about 3 to $5 \mathrm{~m}$ from the western shore of the river Rhine at about $1 \mathrm{~m}$ water depth.

Species were determined and their local abundance was assessed semiquantitatively. Since the species found vary for each sampling, the total number found was clustered into four time periods (until 1980 [period 1], 1981 - 1990 [period 2], 1991 - 2000 [period 3], and 2001 - 2010 [period 4]) in order to investigate trends in abundance over the 34-year sampling period. All fish were also checked visually for overall health status, external abnormalities, and infection with ectoparasites. 
From 1976 to 2010, 29 samplings were taken. In some years between 1976 and 1984 the fish were caught in the spring and autumn in order to determine any differences in the number of species between the two seasons. From 1988 on, electrofishing was mostly executed in autumn. Monitoring was introduced by BASF SE as a commitment to responsible care and also to measure the effects of enhanced water cleaning measures and improved treatment procedures at the site itself [37].

\section{Statistical methods}

For the binary response (species present or not present) increase or decrease in the occurrence by time was tested using SAS procedure Proc Logistic.

This analysis was done separately for each species using logistic regression [38]. The Wald Chi Square test was used to test for an increase or decrease by time. For the number of species a linear regression by time was done using the SAS procedure Proc Reg [39]. It was tested if there is an increase or decrease by time.

\section{Competing interests}

The authors declare that they have no competing interests.

\begin{abstract}
Authors' contributions
SP was part of the project team carried out the last electro fishing in 2010, data collection, literature review and drafted the main sections of the manuscript. JJ was responsible for the organisation of the electro fishing carried out during the time of investigation starting in 1987 and was also part of the experimental project team. Furthermore, he was involved in the literature review and contributed to the historical data of the past electrofishing occasions. TB was part of the experimental project team during the last electrofishing occasion in 2010. $\mathrm{KH}$ was part of the experimental project team during the last electrofishing occasion in 2010 and responsible for coordination of statistical analysis of the results and the critical review of the manuscript. RM was reviewing the last version of the manuscript and gave additional input in that version prior to its interna
\end{abstract} release. All authors read and approved the final manuscript.

\section{Authors' information}

All authors, but Katja Hempel are working at the Department of Products Safety at BASF SE Ludwigshafen as experimental and regulatory ecotoxicologists and toxicologists, respectively. Katja Hempel is now working as a Toxicologist for Abbott GmbH \& CO. KG in the Department of Global Preclinical Safety at Ludwigshafen.

\section{Acknowledgements}

The authors gratefully thank G. Kuhn, Karlsruhe, K. Kuhn, Leimersheim, T. Oswald, SGD Neustadt, U. Pagga, Ludwigshafen and R. Bias, Wachenheim and their coworkers for their collaboration and support during the various electrofishing activities and Martina Dammann for statistical analysis of the data.

\section{Author details}

'Department of Product Safety, BASF SE, GUP/PA, Z 570, Ludwigshafen 67056, Germany. ${ }^{2}$ Department of Product Safety, BASF SE, Ludwigshafen 67056, Germany. ${ }^{3}$ Abbott GmbH \& CO. KG, Global Preclinical Safety, GPRD, Ludwigshafen 67061, Germany.

Received: 25 April 2012 Accepted: 8 October 2012

Published: 17 October 2012

\section{References}

1. Kunz E: Flußbauliche Maßnahmen am Oberrhein von Tulla bis heute mit inren Auswirkungen. In Natur und Landschaft am Oberrhein - Versuch einer
Bilanz. Edited by Hailer N. Speyer: Verlag der Pfalzischen Gesellschaft zur Forderung der Wissenschaften; 1982:34-44.

2. Baldner L: Das Vogel-, Fisch- und Tierbuch. Ludwigshafen: Lauterborn; 1666.

3. Nau BS: Naturgeschichte der Lampetre des Rheins. Schr Ges naturf Freunde Berlin 1787, 1:466-470.

4. Nau BS: Oekonomische Naturgeschichte der Fische in der Gegend um Mainz. Beitr Z Naturgesch D Mainzer Landes 1878, 1:1-120.

5. Nau BS: Nachtrag zur Naturgeschichte der Fische nebst den Amphibien und Vögeln des Mainzer Landes. Beitr Z Naturgesch D Mainzer Landes 1791, 2:121-196.

6. Merrem L: Verzeichnis der rothblütigen Thiere in den Gegenden um Göttingen und Duisburg. Schr Ges naturf Freunde Berlin 1789, 9:1-187.

7. Sanders H: Naturgeschichte der Fische im Rhein. Naturforscher 1780, 15:163-183

8. Anonymus: Hochrhein-Fischfauna im Wandel der Zeit. Natur und Mensch 1992, 2:92-93

9. De Groot SJ: A review of the past and present status of anadromous fish species in the Netherlands: is restocking the Rhine feasible? Hydrobiologica 2002, 478:205-218

10. Sontheimer $H$, Weindel W, Gimbel R: Chemical investigations for evaluating water quality of the Rhine in the year 1975. Bericht der Arbeitsgemeinschaft Rhein-Wasserwerke 1975, 32:15-39.

11. Eizenhöfer W, Benda H: Biologisch-ökologische Gewässergüteuntersuchung des Rheins im Raum Dormagen. Z Abwasser Forsch 1980, 13(2):39-45.

12. Malle KG: Der Rhein: Herkunft der Belastungen und gegenwärtige Gewässerqualität. Chem Ind 1981, 104(6):355-361.

13. Backhaus D, Kemball A: Gewässergüteverhältnisse und Phytoplanktonentwicklung im Hochrhein, Oberrhein und Neckar. Arch Hydrobiol 1978, 82(1/4):166-200.

14. Hellmann H: Load trends of selected chemical parameters of water quality and of trace substances in the river Rhine between 1955 and 1988. Water Sci Technol 1994, 29(3):69-76.

15. Molls F, Nemitz A: Restoration of Atlantic salmon and other diadromous fishes in the Rhine river system. Am Fish Soc Symp 2008, 49:817-834

16. Blasel K: Wiederbesiedlungspotenzial für das Meerneunauge (Petromyzon marinus) im Südlichen Oberrheingebiet, (Regierungsbezirk Freiburg). Freiburg: Regierungspräsidium Freiburg, Fischereibehörde, Referat 33; 2008.

17. Müller D, Kirchesch V: Zur Bedeutung der Nitrifikation für den Stoffhaushalt des Rheins. Korrespondenz Abwasser 1985, 32(6):498-500.

18. Jatzek J: Investigations into fish of the River Rhine in the vicinity of BASF from 1976 to 1990. Fischökologie 1992, 6:31-42.

19. Haider G, Pagga U: Untersuchungen an Rheinfischen im Bereich der BASF. Verhandlungen der Gesellschaft für Ökologie 1981, X:293-297.

20. Malle KG: Der Gütezustand des Rheins. Chemie in unserer Zeit 1991, 25(5):257-267

21. Schulte-Wülwer-Leidig A: The River Rhine. Development of the current water quality from a national point of view. Wasserwirtschaft Wassertechnik 1993, 7:30-35.

22. Caspari M, Goppel M: Development of Water Quality in the River Rhine. In 24 Essener Tagung Wasser und Abfall in Europa. Dresden: Wasser und Abfall in Europa; 1991:141-146.

23. Kieckhäfer $\mathrm{H}$ : Eine versuchsweise elektrische Befischung des badischen Rheines zwischen den Kilometern 360 und 380 im Februar 1971. Der Fischwirt 1971, 21(11):237-240.

24. Mostert E: International co-operation on Rhine water quality 1945-2008 an example to follow? Phys Chem Earth 2009, 34:142-149.

25. Lelek A, Köhler C: Zustandsanalyse der Fischartengemeinschaften im Rhein (1987-1988). Fischökologie 1989, 1(1):47-64.

26. Thielen F, Weibel U, Hirt J, Münderle M, Marten M, Taraschewski H, Sures B: Ichthyofauna in the upper Rhine River close to the city of Karlsruhe as determined by the analysis of fish impingement by cooling-water intakes of a power plant. Limnologica 2008, 38:76-85.

27. Böving H-P: Die Fischfauna des Rheinstromes und seiner direkt angrenzenden Altwässer im Niederrheingebiet. Decheniana (Bonn) 1981, 134:260-273.

28. Gerster S: Hochrhein - Aufstiegskontrollen 1995/96; Vergleich mit früheren Erhebungen; Rückgang der Rotaugenbestände; mögliche Ursachen, Volume 65. Bundesamt für Umwelt, Wald und Landwirtschaft (BUWAL); 1998. 
29. Persat $H$, Copp GH: Electric fishing and point abundance sampling for the ichthyology of large rivers. In Development in electric fishing. Edited by Cowx IG. Oxford: Blackwell Scientific Publications Ltd; 1990:197-209.

30. Weibel U: Neue Ergebnisse zur Fischfauna des nördlichen Oberrheins ermittelt im Rechengut von Kraftwerken. Fischökologie 1991, 5:43-68.

31. Schreiber A, Diefenbach G: Population genetics of the European trout (Salmo trutta L.) migration system in the river Rhine: recolonisation by sea trout. Ecol Freshw Fish 2005, 14:1-13.

32. Lelek A, Pelz GR: Untersuchungen zur ökologischen Bedeutung von Aalen (Anguilla anguilla) und Aalbesatzmaßnahmen. Cour Forsch-Inst Senckenberg 1986, 85:57-64.

33. Müller R: Die Fischfauna im Rhein bei Basel. Verhandlungen der Naturforschenden Gesellschaft Basel 1992, 102(2):343-356.

34. De Groot SJ: Decline and fall of the salmon fisheries in the Netherlands: is restocking the Rhine a reality? Aquac Fish Manag 1992, 23:253-264.

35. Reinartz R, Hilbrich T: Nachweis der marmorierten Grundel (Proterorhinus marmoratus PALLAS, 1811) im unterfränkischen Main bei Eltmann (Rheineinzugsgebiet). Österreichs Fischerei 2000, 53:192-194.

36. Bernauer D, Kappus B, Jansen W: Neozoen in Kraftwerksproben und Begleituntersuchungen am nördlichen Oberrhein. In Neozoen - neue Tierarten in der Natur (Statuskolloquium der Akademie fuer Natur- und Umweltschutz Baden-Wuerttemberg und des Umweltministeriums Baden-Wuerttemberg) 9-10Mai: 1995; Fellbach.: ; 1995:87-96.

37. Kalweit $\mathrm{H}$ : Water quality of the Rhine downstream of the BASF waste water treatment plant during the operational dlsturbance of May 1984. Wasser + Boden 1985, 10:476-481.

38. Allison PD: Logistic regression using the SAS system theory and application. Cary, N.C: SAS Institute; 1999

39. Draper N, Smith H: Applied regression analysis, vol. 3nd. 3rd edition. New York: Wiley; 1998

doi:10.1186/2190-4715-24-28

Cite this article as: Pawlowski et al:: 34 years of investigation in the Rhine River at Ludwigshafen, Germany - trends in Rhine fish populations. Environmental Sciences Europe 2012 24:28.

\section{Submit your manuscript to a SpringerOpen ${ }^{\circ}$ journal and benefit from:}

- Convenient online submission

- Rigorous peer review

- Immediate publication on acceptance

- Open access: articles freely available online

- High visibility within the field

- Retaining the copyright to your article 